\title{
ESTABLISHMENT OF THE CUSTOMER PERSPEC- TIVE OF THE BALANCED SCORECARD SYSTEM AT SPORTS ENTERPRISES THROUGH THE EXAMPLE OF A HUNGARIAN FOOTBALL CLUB
}

\author{
Vilmos Lakatos ${ }^{1}$, László Erdey ${ }^{2}$, Szúcs Norbert $^{3}$, Attila Rózsa ${ }^{4}$, Adrián Nagy ${ }^{5}$ \\ ${ }_{1,2,4,5}$ Faculty of Economics and Business University of Debrecen, Hungary
}

\begin{abstract}
In our present world, more and more attention is being paid to the evaluation and monitoring of different sports organizations, which is because the support of spectator sports has become an important issue. Our fundamental assumption is that football clubs of our time should operate just like large companies in the business sectors. Obviously, it is an essential prerequisite that controlling, a controlling system or a performance measurement system be applied at the business entities operating the clubs. According to our experience, conscious financing of organizations is often neglected in the course of the management processes of sports companies. It is necessary to create the conditions at these organizations that enable managerial decision support and the establishment of a controlling system. It is essential to find controlling methods and tools that can be successfully applied in the life of a sports organization and that ensure the harmonization and coordination of different processes. Consequently, controlling provides a higher level of transparency and information supply for decision makers. The aim of present study is to introduce the Balanced Scorecard (The Balanced Scorecard is a balanced strategic system of indexes, which measures the performance of companies for the sake of implementing the strategy), one of the tools of strategic controlling and its application to sports companies through an example of a Hungarian football club.
\end{abstract}

Keywords: performance measurement, controlling, index system, Balanced Scorecard, decision support (JEL Classification: Z23) 


\section{INTRODUCTION}

Currently, the role of sports has intensified and changed; by now, it has become a separate area of interest from an originally civil, exercise-based, private leisure activity. One of the reasons for the development of sport activities was the increase of their economic significance, which created the need for their economic analysis (ÁCS, 2015; BÁCSNÉ et al., 2018b). In modern societies, the role of sport has increased significantly, as the sports market has undergone explosive development. It was accompanied by an increase in its economic weight. In many countries, sport is considered a profitable sector and its economic importance has increased. The reason for the dynamic development of the leisure market of the sports industry is the increase of demand for sports opportunities due to leisure and lifestyle changes. This provides a constantly expanding market for companies providing sports services and businesses dealing with sports tourism and sports equipment production (ANDRÁS, 2003; BÁCSNÉ et al., 2018c). Following the improvement of the economic importance of sport, the association-based sport model had to be replaced by the business model (BÁCSNÉ, 2015a). Sport had to be produced as a service and its owners became profit-oriented (VÁCZI, 2010). In developed countries, sport is already managed by the market and its subsistence is not based on state support. The market presence of sport as a service is still in its infancy in Hungary (BÁCSNÉ, 2015b). According to DÉNES (2015) a sports economist, sport has to significantly reconsider its method of thinking and acting; management of successful sports has to be changed. There are some spectator sports that enjoy great success abroad, but they are not popular in Hungary. Federations of various wellknown sports are struggling with financial difficulties and can only rely on the government. The power of sports favoured by the market lies in their large advertising media value, which is due to their considerable requirement of sports equipment and their spectacles. Other sports (canoeing, kayaking, swimming), however, are only valued on the basis of the number of Olympic medals (DÉNES, 2015). Based on the research of RÁTONYI ez al.(2017), it was also concluded that sport is a multi-billion-dollar economic area, one of the most dynamically developing industries in the world. Contribution of the sports sector to GDP in the EU Member States is close to $5 \%$, while in Hungary it is approximately $1-1.5 \%$. This ratio is likely to increase, for which various subsidies of corporate tax provide a good basis.

According to SZABADOS (2008), it seems that global football is increasingly characterized by globalization and uniformity: the same techniques and solutions appear in Madrid, Manchester, Milan, Marseille or even in Miskolc. Tools are undoubtedly similar, however the objectives and structures sometimes show surprising variability. Each football club follows its own ideas and its own strategy with strict consistency: this awareness is the most important indicator of these organizations being professional business enterprises. Furthermore, nowadays football clubs attract the interest of investors in the same way as regular enterprises, an evidence of which is that the well-known methods used for valuing firms and brands (presented by Takacs $(2014,2015)$ for instance) are now applied for football clubs, and market values of the best teams are regularly revealed (e.g. Forbes's annually published List of Most Valuable Soccer Teams). The age of amateur associations has ended; enthusiastic nonprofessionals disappeared not only from the fields but also from club houses, and football companies consciously select and follow strategies as their teams do on the field. On the international level, Hamil et al. (2010) state that since the 1990s the process of sports becoming more business-like has had numerous consequences.

It can be stated that in the 21st century, demand for sport has progressed enormously, resulting in the development of the economic aspects of sports as well. Governments play an essential role in filling the funding gap, which is required for the sustainable operation of sports. In Hungary, government intervention and funding is considerable. Currently, increasing amounts of funding is involved in sport and more and more attention is paid to the social usefulness of sporting activities (VÁCZI et al. 2017, BÍRÓ et al. 2017), however many organizations are struggling to survive (KOZMA and KAZAINÉ, 2014b). BÁCSNÉ et al. (2018a) stated that the economic performance of Hungarian football clubs is lagging behind the international ones, and that the total revenue of 9 National League I football clubs examined by them amounts to $11.10 \%$ of the total revenue of domestic profit-oriented sport companies and $2.80 \%$ of the revenue of the entire sports sector. Thus, economic importance of the leading professional football companies is indeed significant.

The recent change in the life of sports organizations makes it necessary to introduce some form of managerial decision support that ensures that managers of sports companies are in possession of the information they need to make a proper decision in different decision-making situations (FENYVES, 2014). It would be important for sports companies to use different decision support tools developed in corporate practice, therefore a well-designed controlling system or even the application of certain controlling methods can contribute to the success of decisions. The environment of companies has changed over the recent years, and the lives of organizations are characterized by an increasingly dynamic, non-transparent and rapidly changing environment (VERESNÉ, 2013). Currently, only those organizations that are able to provide positive feedback on environmental change can retain their competitiveness (SZÉLES et al., 2014, HÁGEN, 2017, FENYVES et al., 2018). Due to unpredictable changes, long-term forecasts and plans have become unwarrantable, intuitions can no longer be relied upon, therefore the introduction of new solutions became necessary (MUSINSZKI, 2014, BÖCSEKI et al, 2015). The role of controlling activity has become more emphasized in the life of business organizations; it has become necessary to break down long-term plans into short-term plans, to observe changes in the environment and to compare them with the set 
objectives. Multiple strategic performance measurement tools and index systems have been developed to support controlling activities (FENYVES et al., 2016, KOCZISZKY-VERESNÉ, 2016), such as the Balanced Scorecard system (KAPLAN and NORTON, 2004), Tableau de Bord (RODNISKI et al., 2013), Performance Prism (KUCSMA, 2017).

\section{MATERIALS AND METHODS}

Balanced Scorecard is a balanced strategic index system that measures the performance of companies for the sake of the realization of their strategy. Thus, BSC is one of the bestknown examples of performance measurement systems, which helps in creating balance among the various strategic indexes (ROBERT and VIJAY, 2009, SZÓKA, 2017, HOTVÁTHOVÁ et al., 2015).

There is not much experience yet in terms of using Balanced Scorecard at sports organizations; relatively few technical literature deals with its introduction and application of sports organizations. As a pioneer in the history of football, the management of the German football club VfB Stuttgart applied BSC first, the process was led by Professor Péter Horváth of Hungary and his company. The effect of the BSC on the football club was clearly positive. With this step, the club started proceeding towards professional and effective management decisions.

The Balanced Scorecard can help managers of sports organizations as follows:

- BSC forces managers to clarify the strategic goals of their sports organization and to reconsider what steps they need for achieving and realizing these objectives;

- it forces a multi-faceted approach;

- drawing a cause-and-effect chain requires strong strategic thinking. The relationship between the operation and success of the organization also has to be examined and last but not least, different objectives need to be harmonized;

- it is a common communication tool for management members and it also represents a common objective

- annual planning and preparation of the budget can be linked to it

- it works as a formalized framework for monitoring the performance of the organization,

- it promotes the strategic learning process;

- it can also be used for motivational purposes.

It is important for the BSC to be easily comprehensible and an understandable and usable index system for sports professionals and sports managers. Particular attention should be paid to the placement of sports performance - which is one of the most important performance dimensions for sports organizations or in this case football clubs - in one of the four dimensions. Sports performance is one of the most important categories; however, it is not recommended to treat it separately, but to integrate it into the different perspectives (KOZMA and KAZAINÉ, 2014a).

As for the already mentioned VfB Stuttgart German football club, in 2004 Erwin Staudt, president of the club, commissioned the consulting firm Horvath \& Partners to perform this pioneering task. This initiative and work could start with a significant change in the club's management, namely that Erwin Staud was appointed president of the team. One of his primary objectives was to develop professional management within the club. It is important to mention that prior to being appointed president of the team he was the manager of IBM in Germany. He immediately made two important decisions; firstly, he involved managers who are successful in other areas of business life into the management of the club and secondly he developed the Balanced Scorecard system.

The introduction of a balanced strategic index system at the VfB Stuttgart football club was a pioneering initiative. In the course of establishing the system, experts explored and analysed organizations working close with the club, as well as a number of other participants such as professional sports associations, spectators, fans, governing and managing organizations of the league, media representatives and sponsors. The analysis identified the objectives and expectations of the various participants and the system of interrelated activities. In addition, performance relationships amongst them were also analysed.

As a next step, after becoming familiar with the environment behind the operating framework, the strategic objectives of the football club designated along the following four perspectives: 1. financial perspective, 2. sports professional perspective, 3. customer perspective, 4 . internal processes and potentials perspective.

As a result of the above, the comprehensive goals have been developed into such objectives and measures for the club managers that can be interpreted at all levels of the organization; indexes analysing the fulfilment of these objectives have also been elaborated. 130 indexes have been identified, the most important 30 of which provide comprehensive information to managers about the achievement of the set objectives, while the other 100 indexes provide information to sub-managers of different areas (Horvath \& Partners, 2004).

For example, the introduction of BSC includes the strategic objective to create a strong and stable economic background and to reduce the amount of debt. Strict management was required to prevent the club from getting into a situation it did in the 1999 season, when the club accumulated EUR 16 million of debt.

The football club had a total budget of 46 million EUR at that time. The indexes analysing the financial management of the club cover all areas, which have a role in the development of incomes and expenses. Income indexes have an especial importance, which - among others - involve:

- attendance at games,

- sponsoring contracts,

- sales of VIP seats,

- services within the sports facility,

- and television royalties.

In addition to the above-mentioned economic and financial indexes, special attention is given to the development of junior athletes. Development of this new generation has special 
attention, because as in the life of companies in other markets, where it is necessary to dedicate considerable resources for research and development in order to achieve future business results and success, a similar amount of attention and money must be dedicated to junior athletes in football as well. The most important indicator of the performance of the junior training is the inclusion rate of self-trained players in the league games. According to reports, this was over $30 \%$ in the life of the Stuttgart football club.

Overall, introducing Balanced Scorecard, Stuttgart has taken a huge step towards professional management and leadership. The explicit objective of the management was to maintain the initial economic success not only in the short term, but also in long term. The management was committed to governing the football club on a professional basis, just as successful business companies in the business sector (HORVATH \& PARTNERS, 2004, SUHÁNYIOVÁ et al., 2015).

As for Hungarian football and Hungarian football clubs, there is no knowledge of the introduction of a similar system or application of the BSC system by any of the sports organizations. In the summer of 2015, the Hungarian Football Federation (MLSZ) launched its Financial Monitoring online data supply system (PMR) for football clubs included in both National League I and II.

Currently, more and more interest is taken in the social benefit of sporting activities (BORBÉLY and MÜLLER 2015, MÜLLER et al. 2016), however many sports organizations in Hungary are forced to fight for survival and against bankruptcy. It is noticeable that in Hungary most sports organizations have their focus on measuring sports performance. Modern sports clubs should operate as large companies in business sectors, and still relatively low attention is paid to measuring business performance and the factors affecting it. Despite the fact that relatively low emphasis is put on measuring these factors, sport club managers are aware of the interdependence of sport performance and business performance (KOZMA and KAZAINÉ, 2014c).

Unfortunately, the market alone is not able to maintain football clubs in Hungary yet. In major football markets such as the Premier League, where there are methods and opportunities for clubs to operate on a business basis, the basic purpose of sports organizations is the same as that of companies in traditional markets: the objective is to satisfy consumer needs while achieving profit. However, business considerations in Hungary are largely intertwined with the values of society, and the investment-oriented behaviour of local and central government has a prominent role in Hungarian football.

There are two kinds of success in football and in any other sports as well:

- sports professional success

- economic success

Sustainable operation is becoming more and more important at various sports clubs. Professional success, namely excellent sports results, usually attract attention. This professional success is not only socially beneficial, but also financially, because the professional success of the sports industry expands commercial opportunities and through this business potential, management of the organization can be placed on a business basis. The ultimate result of this may be that sports organizations are able to untie themselves from the funding policies of the currently governing party.

Nevertheless, the financial dimension of the Balanced Scorecard cannot be the most important aspect in the case of sports organizations. Out of four perspectives of the balanced scorecard system, emphasis should be put on the customer perspective, as is the case for non-profit organizations (BECSKY, 2011).

\section{RESULTS AND DISCUSSION}

Taking technical literature into consideration, a possible Balanced Scorecard index system for DVSC FUTBALL Ltd. was set up. Being aware of the objectives of the DVSC from previous chapters, and following consultations with the company manager, the focus of this club is on the customer perspective, of course not neglecting the indexes of the other three perspectives; according to the technical literature appropriate focus needs to be on the financial and non-financial indexes as well. In present study, the aim is to introduce the customer perspective.

According to HÁGEN and KONDOROSINÉ (2011), in the case of the customer perspective, managers recognize consumer and market segments where the organization intends to compete. The customer perspective of the Balanced Scorecard enables the company to harmonize the most important indexes related to customers with the demands of the selected customer and market segments. For consumers, products and services that create value are the most important performance drivers of result indicators. According to Horvath \& Partners (2008), the customer perspective answers the following question: "How should we appear in the eyes of customers to be successful in implementing our strategy?"

Companies, in this case football clubs, need to identify existing market segments within the current and potential future customer base. After identification, segments that the clubs intend to compete with have to be selected. The basic groups of indexes of the customer perspective are the following:

- market share,

- retained/returned customers,

- new customers,

- customer satisfaction,

- customer profitability.

These five indexes are generally applicable for all organizations (HÁGEN and KONDOROSINÉ, 2011). In the case of sports organizations, also in the case of DVSC, the difficulty is caused by the fact that different consumer groups can be identified in different football markets. Five markets of football can be distinguished: consumer market, market for broadcasting rights, sponsorship market, player market and merchandising market (ANDRÁS, 2004).

According to HÁGEN and KONDOROSINÉ (2014a), in terms of strategy, customers belonging to the consumer 
market, namely the fans are the most important from among the above-mentioned ones; they can be local spectators or fans who are engaged through various media. Fans are the most important because they are able to influence the demand of other consumers in a positive direction with their presence. For example, if the atmosphere of a stadium is lively, it generates a more marketable product for the media and sponsors. However, the majority of sports club revenues in Hungary come from different sponsors who have a commercial and political interest in supporting the given football team. There are basic indexes in the case of sports organizations as well to measure the performance of the customer perspective; these indexes are the same as the ones used in different industries. They are the following:

- market share (within a relevant geographic area),

- attendance at games,

- average consumer spending, etc.

There is a very special dimension of the performance of sports organizations, which is the sports success experienced by the consumers, the reason for which is subjective perception. Club fans are not only interested in the number of trophies acquired during the season, but also in a performance that matches initial expectations, the quality of the opponents, current form/condition of the team, etc. This is a critical factor for the management: on the one hand, it is difficult to manage on the other hand the focus needs to be on the team in order to achieve the objectives of the sports organization. There is no performance indicator, which could alleviate the disappointment of fans felt because of poor performance on the football field. Experience of consumers and fans might benefit from the creation of a so-called comfort feeling of the game day and other days. Non-game day services and events also help the club achieve success in the business by directly boosting revenues and promoting bonding with the club. Such events include various open days, family programs, which also attract women and children to the stadium who would never go to football games. For fans, the impression, opinion and positive image of the facility and its staff is very important, since it can contribute to the attendance of football games (HÁGEN and KONDOROSINÉ, 2014).

Due to the poor game results of the last 3 years, the DVSC football club has to consciously build a long-term relationship with the consumers in order for spectator fans, sponsors and the media to stay with the team despite the fluctuation of sports performance. Relationship with consumers is very important for every sports organization; it is the key for achieving success. Emotional attachment of fans to the team is considered normal, but sponsors and the media are much less loyal, they could leave the team sooner due to the poor performance. In most cases, media is likely to broadcast the games of the best performing team, or football club or they focus viewer attention on their games. Finally yet importantly, sports organizations, in this case the DVSC football club, must manage their reputation and brand name, which are key factors in the transition to a business based operation.

There is a divergence of opinion in foreign technical literature, regarding how brand value can be measured in the case of football clubs. However, opinions agree that the image of a team can maintain popularity even when performance does not exactly meet the expectations. Possible indexes of this perspective are the following:

- rate of attendance at sports events, in this case football games, compared to the total attendance of sports events in the city and its catchment area, the annual increase in attendance,

- newly concluded sponsorship contracts

- number of games broadcasted in national media,

- attendance at no-game events

- consumer activity on electronic platform (HÁGEN and KONDOROSINÉ, 2014).

Based on the above, the following indexes were set up in the customer perspective of DVSC FUTBALL Ltd. According the management, the objective of the DVSC football club is identical with the expectations of customers, namely for the club to achieve sports professional success.

The first index number that was set up is the attendance of home games in the 2016/2017 championship season and the 2017/2018 championship season, which are shown in Table 1 and Table 2.

Table 1: Attendance of spectators during the 2016/2017 championship season

\begin{tabular}{|c|c|c|l|c|c|}
\hline \multicolumn{5}{|c|}{ Attendance } \\
\hline \multicolumn{5}{|c|}{ Debreceni VSC - 2016/2017 NB I. } \\
\hline No. & Date & $\begin{array}{c}\text { Home } \\
\text { team }\end{array}$ & $\begin{array}{c}\text { Visitor } \\
\text { team }\end{array}$ & Attendance & Result \\
\hline 1. & 2016.07 .17 & DVSC & Paksi Fc & 2851 & $1-1$ \\
\hline 2. & 2016.07 .31 & DVSC & Gyirmót Fc & 2463 & $4-0$ \\
\hline 3. & 2016.08 .13 & DVSC & MTK & 4091 & $1-1$ \\
\hline 4. & 2016.08 .17 & DVSC & Szombathely Haladás & 2367 & $0-1$ \\
\hline 5. & 2016.09 .10 & DVSC & Újpest & 4081 & $2-1$ \\
\hline 6. & 2016.09 .20 & DVSC & Budapest Honvéd & 1685 & $0-1$ \\
\hline 7. & 2016.10 .22 & DVSC & Vasas & 3723 & $1-2$ \\
\hline 8. & 2016.11 .05 & DVSC & Mezőkövesd Zsóry & 2385 & $0-0$ \\
\hline 9. & 2016.12 .03 & DVSC & Videoton & 1814 & $0-1$ \\
\hline 10. & 2017.02 .18 & DVSC & FTC & 7138 & $0-0$ \\
\hline 11. & 2017.03 .04 & DVSC & DVTK & 4214 & $3-0$ \\
\hline 12. & 2017.03 .11 & DVSC & Paksi Fc & 3021 & $1-3$ \\
\hline 13. & 2017.04 .08 & DVSC & Gyirmót Fc & 2237 & $2-1$ \\
\hline 14. & 2017.04 .15 & DVSC & MTK & 2363 & $0-0$ \\
\hline 15. & 2017.04 .22 & DVSC & Szombathely Haladás & 2039 & $4-2$ \\
\hline 16. & 2017.05 .06 & DVSC & Újpest & 5112 & $1-0$ \\
\hline 17. & 2017.05 .20 & DVSC & Budapest Honvéd & 6328 & $2-5$ \\
\hline & & Total & 57912 & \\
\hline & & Average & 3407 & \\
\hline & & Utilisation rate & \\
\hline & & & & \\
\hline
\end{tabular}

Source: Own editing based on the data of DVSC FUTBALL Ltd. (2018) 
Table 1 shows that the average number of spectators was 3407 in 17 home games; the game played against Ferencváros TC stands out, it was watched by more than 7000 people at the Debrecen Nagyerdei Stadium.

Table 2 shows that during the 2017/2018 championship season, there were a little more than 16000 spectators at two home games played against Ferencváros TC. It can be seen that fans were much more interested in the games played against Ferencváros than the others. This higher number of attendance is also because the FTC has a very large fan base, who travel with the team to their away games.

Table 2: Attendance of spectators in the 2017/2018 championship season

\begin{tabular}{|c|c|c|l|c|c|}
\hline \multicolumn{5}{|c|}{ Attendance } \\
\hline \multicolumn{5}{|c|}{ Nobreceni VSC - 2017/2018 NBI. } \\
\hline No. & Date & $\begin{array}{c}\text { Home } \\
\text { team }\end{array}$ & $\begin{array}{c}\text { Visitor } \\
\text { team }\end{array}$ & Attendance & Result \\
\hline 1. & 2017.07 .15 & DVSC & Mezökövesd Zsóry & 4401 & $1-2$ \\
\hline 2. & 2017.08 .06 & DVSC & FTC & 5306 & $0-0$ \\
\hline 3. & 2017.08 .18 & DVSC & Vasas & 3634 & $4-1$ \\
\hline 4. & 2017.09 .09 & DVSC & DVTK & 5538 & $3-1$ \\
\hline 5. & 2017.09 .23 & DVSC & Puskás Akadémia & 3241 & $3-0$ \\
\hline 6. & 2017.10 .21 & DVSC & Szombathely Haladás & 6025 & $1-1$ \\
\hline 7. & 2017.10 .28 & DVSC & Paksi FC & 2802 & $3-2$ \\
\hline 8. & 2017.11 .18 & DVSC & Videoton & 3200 & $2-5$ \\
\hline 9. & 2017.12 .02 & DVSC & Budapest Honvéd & 2521 & $1-0$ \\
\hline 10. & 2018.02 .24 & DVSC & Balmazújváros & 1824 & $0-2$ \\
\hline 11. & 2018.03 .10 & DVSC & Újpest & 2701 & $1-2$ \\
\hline 12. & 2018.03 .17 & DVSC & Mezókövesd & 1512 & $2-3$ \\
\hline 13. & 2018.04 .14 & DVSC & FTC & 10841 & $1-1$ \\
\hline 14. & 2018.04 .28 & DVSC & Vasas & 3214 & $2-3$ \\
\hline 15. & 2018.05 .12 & DVSC & DVTK & 3383 & $2-1$ \\
\hline 16. & 2018.05 .27 & DVSC & Puskás Akadémia & 2414 & $1-1$ \\
\hline & & Total & 62557 & \\
\hline & & Average & $19,22 \%$ & \\
\hline & Seating capacity of the stadium is 20340 & \\
\hline & & & & & \\
\hline
\end{tabular}

Source: Own editing based on DVSC FUTBALL Ltd. (2018) the average number of spectators also increased by 503 , and the utilization rate of the Nagyerdei Stadium was also higher in the 2017/2018 championship season; it increased from $16.75 \%$ to $19.22 \%$. The growth of these ratios was on the one hand because the club re-appointed its previously successful coach András Herczeg for the 2017/2018 championship season, as well as because of the better sports performance, since while the team finished only in the 8th place in the 2016/2017 championship season, it was the 5th in 2017/2018. Initiatives successfully implemented by the marketing department of the club cannot be disregarded either. These initiatives focus on bringing the club's fans and players closer together, and on promoting the club to attract as many potential fans as possible. The initiated efforts include:

- school roadshow,

- fan meetings with players,

- fan clubs,

- open days,

- competitions, games during the half time of home games, for example penalty kicks, etc.

- launching of Loki Tv, which among others follows the lives of the players,

- "Miss Loki" beauty pageant,

- participation in different charities, for example the club teamed up with Dr. Zsolt Horváth, former DVSC player and raised more than 500,000 HUF for the Childrens' Heart Foundation (Gyermeksziv Alapítvány) in April 2017. In December 2016, the club together with the Hope for Children with Leukemia Foundation purchased a patient monitor for 500,000 HUF for the Department of Children's Haematology and Oncology of the University of Debrecen (DVSC FUTBALL Ltd, 2018).

Attendance of DVSC games was compared to the attendance of sports events within the region, namely the attendance of Balmazújváros (National League I football club) Diósgyőr VTK of Miskolc (National League I football club) and the DVSC - TVP Debrecen women's handball team, as shown in Table 3.

Table 3 shows that games of DVSC football club had

Table 3: Comparison of the attendance of DVSC games to the attendance of other sports clubs

Comparing the attendance data of the last two championship seasons, it can be seen that the home games of DVSC football club were attended by 4645 more people in the 2017/2018 championship season, however as shown in the tables, the team had a home game less in the last season. Consequently,

\begin{tabular}{|c|c|c|c|c|c|c|}
\hline $\begin{array}{c}\text { Name of the } \\
\text { sports club }\end{array}$ & Section & $\begin{array}{c}\text { "Championship } \\
\text { season" }\end{array}$ & $\begin{array}{c}\text { Seating ca- } \\
\text { pacity of the } \\
\text { sports facility }\end{array}$ & $\begin{array}{c}\text { "Total } \\
\text { attendance" }\end{array}$ & $\begin{array}{c}\text { "Average } \\
\text { attendance" }\end{array}$ & $\begin{array}{c}\text { "Utilisation rate } \\
\text { of the sports } \\
\text { facility }(\%) "\end{array}$ \\
\hline DVSC & $\begin{array}{c}\text { "National Football } \\
\text { League I" }\end{array}$ & $2016 / 2017$ & 20340 & 57912 & 3407 & $16,75 \%$ \\
\hline DVSC & $\begin{array}{c}\text { "National Football } \\
\text { League I" }\end{array}$ & $2017 / 2018$ & 20340 & 62557 & 3910 & $19,22 \%$ \\
\hline Balmazújváros & $\begin{array}{c}\text { "National Football } \\
\text { League I" }\end{array}$ & $2017 / 2018$ & 2250 & 24075 & 1505 & $66,88 \%$ \\
\hline DVTK & $\begin{array}{c}\text { "National Football } \\
\text { League I" }\end{array}$ & $2017 / 2018$ & 16245 & 52564 & 3285 & $20,22 \%$ \\
\hline DVSC-TVP & $\begin{array}{c}\text { "Women's Hand- } \\
\text { ball League I" }\end{array}$ & $2017 / 2018$ & 2256 & 18400 & 1415 & $62,74 \%$ \\
\hline
\end{tabular}

Source: Own editing, based on Lang (2018). 
the highest total attendance in the $2017 / 2018$ championship season, and average number of spectators also belongs to DVSC in Hajdú-Bihar county. Attendance of the DVTK football club was compared to the attendance of DVSC, because during the $2017 / 2018$ season, DVTK played its home games at the Debrecen Nagyerdei Stadium due to the construction of its own stadium. DVSC does not only have outstanding attendance data within the region, but it also stands out from amongst its competitors on a national level. The football club operated by DVSC FUTBALL Ltd. had the second highest attendance in Hungary in the 2017/2018 championship season. FTC football club was the first in terms of the total attendance of home games, with 154,758 spectators (LANG, 2018).

Despite all this, the club and the club management still have plenty of work to do; examination of the utilization rates of sports facilities shows a lot worse and more realistic image about the current attendance rate of Hungarian football clubs. Table 3 shows that DVSC FUTBALL Ltd. has a stadium with the highest seating capacity in the region, which in the $2016 / 2017$ season was utilised only at a $16.75 \%$ rate, however in the $2017 / 2018$ season this rate has increased to $19.22 \%$. Comparison of the above data to the stadium utilization rate of the Balmazújváros football club, shows that it was $66.88 \%$ in the $2017 / 2018$ championship season, thus it can be concluded that DVSC is far below that. The same can be stated about the utilization rate of the DVSC - TVP women's handball club.

At the same time, it should not be overlooked that both the stadium of Balmazújváros and the sports arena of the DVSC - TVP have much smaller seating capacities; the capacity of both facilities is approximately 2250 people which is much less than the 20340 seats of the Nagyerdei Stadium. The most relevant comparison base is the DVTK football club, because, as mentioned above it played its home games at the Nagyerdei Stadium in Debrecen during the 2017/2018 championship season. Table 3 shows that there is hardly any difference between the stadium utilization rate of the two football clubs, DVSC and DVTK. It can be seen that DVTK precedes the utilisation rate of DVSC's stadium utilization rate by only $1 \%$, which, taking into account the average number of spectators (which is behind the value of the DVSC football club), may also be due to the fact that the DVTK only rented a certain part of the seats of the Nagyerdei Stadium (16 245 seats), while DVSC has a total of 20

\section{0 seats.}

Figure 1 shows attendance data, while Table 2 includes the data of stadium utilisation rate.

Figure 1: Attendance data of the 2017/2018 championship season Source: Own editing based on LANG (2018)

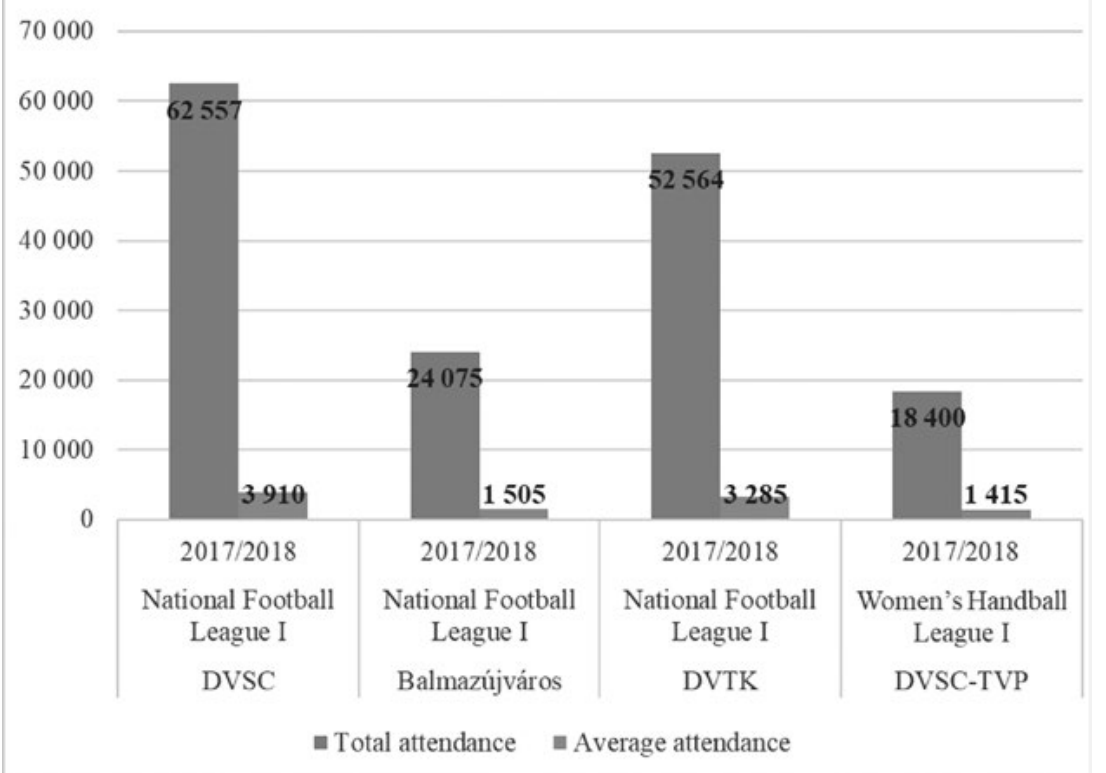

Figure 2: Utilisation rate of sports facilities in the 2017/2018 championship season

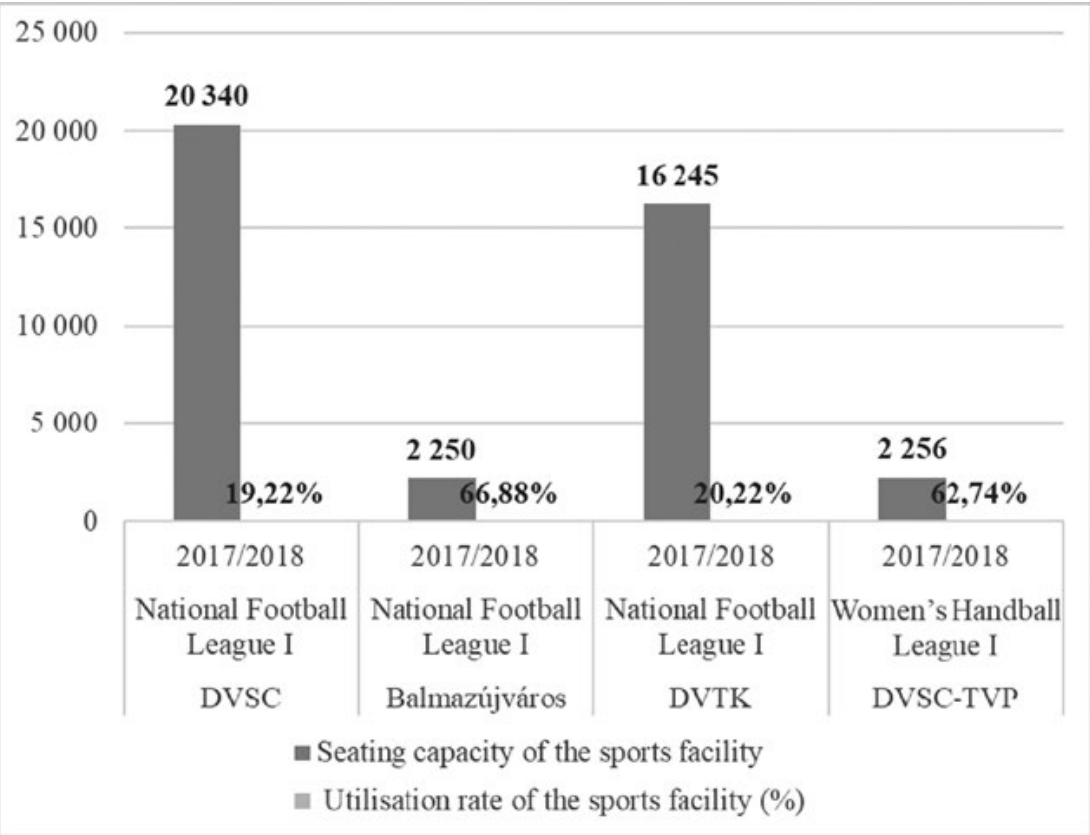

Source: Own editing based on LANG (2018)

The following index numbers refer to the popularity of the online platforms. As mentioned earlier, the consumers are in constant change, and thus consumer needs also keep changing. It is not entirely sure that 
the currently growing new generation is interested in the games of the teams only, nor is it sure that the current young generation intends to sit in the stadium for 90 minutes or spend 90 minutes watching their favourite team on TV. It needs to be accepted that in the accelerated world of our age and due to the diverse social media, new types of consumers and fans have appeared who only want to follow their favourite teams or their favourite players on digital platforms. Consequently, DVSC also largely focuses on social media. In addition to the DVSC website, it also has its own Facebook, Twitter, Instagram pages, and it is also present on various video sharing websites with its own produced programme called Loki TV.

Figure 3 shows the follower and visitor data of the Facebook, Twitter, and Instagram social media platforms of the DVSC football club.

Figure 3: Followers and visitors of DVSC on social media platforms

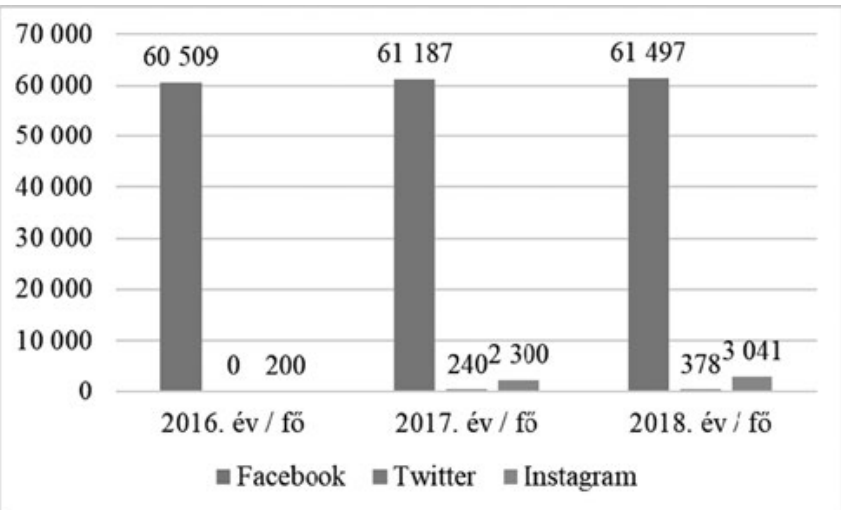

Source: Own editing based on DVSC FUTBALL Ltd. (2018)

Figure 3 illustrates that the Facebook social media page of DVSC has the largest number of followers; it has more followers every year and this growth can be seen in the case of both its Twitter and Instagram platforms. Popularity data of the social media platforms of DVSC prove that the club has numerous fans who follow the team and the events surrounding the team through different social media. The reason for this is that the marketing department of the club places great emphasis on keeping these sites up-to-date and providing new information, interesting topics and news for the fans about their favourite team. The interest in these online platforms might encourage potential and existing sponsors to support the DVSC football club, as it has a substantial follower base, therefore existing or potential new sponsors will not only reach the people watching games in the stadium through the club but also reach the young generation who follow the team on the internet.

Table 4 shows that the DVSC football club had the $3 \mathrm{rd}$ highest number of Facebook followers in 2018.
Table 4: Facebook followers of the National League I football clubs in 2018

Facebook followers of the National League I football clubs in 2018

\begin{tabular}{|c|c|c|}
\hline No. & Club & 2018. year/person \\
\hline 1. & Ferencváros & 229975 \\
\hline 2. & Videoton & 68037 \\
\hline 3. & DVSC & 61497 \\
\hline 4. & Diósgyőr & 59976 \\
\hline 5. & Budapest Honvéd FC & 39870 \\
\hline 6. & Újpest FC & 36315 \\
\hline 7. & Puskás Akadémia & 15744 \\
\hline 8. & Haladás & 14160 \\
\hline 9. & MTK & 12297 \\
\hline 10 & Paks & 9263 \\
\hline 11. & Mezőkövesd & 6939 \\
\hline 12. & Kisvárda & 4781 \\
\hline
\end{tabular}

Sources: Own editing based on the Facebook pages of the football clubs.

The third index number is the number of games broadcasted by national media. Table 5 and Table 6 show games of the DVSC football club that were broadcasted by national media in the last two championship seasons.

Table 5: TV broadcasted games of DVSC during the 2016/2017 National League I championship season

TV broadcasted games of DVSC during the 2017/2018 National League I championship season

\begin{tabular}{|c|c|c|c|c|c|}
\hline No. & Date & Home team & Visitor team & $\begin{array}{l}\text { champion- } \\
\text { ship season }\end{array}$ & TV channel \\
\hline 1. & 2016.07.24 & Vasas & DVSC & $2016 / 2017$ & M4 sport \\
\hline 2. & 2016.08 .13 & DVSC & MTK & $2016 / 2017$ & M4 sport \\
\hline 3. & 2016.08 .17 & DVSC & Haladás & $2016 / 2017$ & M5 \\
\hline 4. & 2016.08 .21 & Videoton & DVSC & $2016 / 2017$ & M5 \\
\hline 5. & 2016.09 .10 & DVSC & Újpest Fc & $2016 / 2017$ & M4 sport \\
\hline 6. & 2016.09 .17 & Ferencváros & DVSC & $2016 / 2017$ & M4 sport \\
\hline 7. & 2016.09 .20 & DVSC & $\begin{array}{c}\text { Budapest } \\
\text { Honvéd FC }\end{array}$ & $2016 / 2017$ & M4 sport \\
\hline 8. & 2016.09 .24 & Diósgyôr & DVSC & $2016 / 2017$ & M4 sport \\
\hline 9. & 2016.10 .22 & DVSC & Vasas & $2016 / 2017$ & M4 sport \\
\hline 10. & 2016.12 .03 & DVSC & Videoton & $2016 / 2017$ & M4 sport \\
\hline 11. & 2016.12 .10 & Újpest FC & DVSC & $2016 / 2017$ & M4 sport \\
\hline 12. & 2017.02 .18 & DVSC & Ferencváros & $2016 / 2017$ & M4 sport \\
\hline 13. & 2017.02 .25 & $\begin{array}{c}\text { Budapest } \\
\text { Honvéd FC }\end{array}$ & DVSC & $2016 / 2017$ & M4 sport \\
\hline 14. & 2017.04 .15 & DVSC & MTK & $2016 / 2017$ & M4 sport \\
\hline 15. & 2017.04 .29 & Videoton & DVSC & $2016 / 2017$ & M4 sport \\
\hline 16. & 2017.05 .13 & Ferencváros & DVSC & $2016 / 2017$ & M4 sport \\
\hline 17. & 2017.05 .20 & DVSC & $\begin{array}{c}\text { Budapest } \\
\text { Honvéd FC }\end{array}$ & $2016 / 2017$ & M4 sport \\
\hline
\end{tabular}

Source: Own editing based on DVSC FUTBALL Ltd. (2018) 
Table 6: TV broadcasted games of DVSC during the $2017 / 2018$ National League I championship season

\begin{tabular}{|c|c|c|c|c|c|}
\hline No. & Date & Home team & Visitor team & $\begin{array}{l}\text { champion- } \\
\text { ship season }\end{array}$ & $\begin{array}{c}\text { TV chan- } \\
\text { nel }\end{array}$ \\
\hline 1. & 2017.07.22 & Haladás & DVSC & $2017 / 2018$ & $\begin{array}{c}\text { Duna } \\
\text { World }\end{array}$ \\
\hline 2. & 2017.08 .06 & DVSC & Ferencváros & $2017 / 2018$ & M4 sport \\
\hline 3. & 2017.08.12 & Videoton & DVSC & $2017 / 2018$ & M4 sport \\
\hline 4. & 2017.08 .18 & DVSC & Vasas & $2017 / 2018$ & M4 sport \\
\hline 5. & 2017.08 .26 & $\begin{array}{l}\text { Budapest } \\
\text { Honvéd FC }\end{array}$ & DVSC & $2017 / 2018$ & M4 sport \\
\hline 6. & 2017.09.16 & Balmazújváros & DVSC & $2017 / 2018$ & M4 sport \\
\hline 7. & 2017.11 .04 & Ferencváros & DVSC & $2017 / 2018$ & M4 sport \\
\hline 8. & 2017.11.18 & DVSC & Videoton & $2017 / 2018$ & M4 sport \\
\hline 9. & 2017.12.02 & DVSC & \begin{tabular}{|c|} 
Budapest \\
Honvéd FC
\end{tabular} & $2017 / 2018$ & M4 sport \\
\hline 10. & 2017.12.09 & Diósgyốr & DVSC & $2017 / 2018$ & M4 sport \\
\hline 11. & 2018.03 .03 & $\begin{array}{l}\text { Puskás Aka- } \\
\text { démia }\end{array}$ & DVSC & $2017 / 2018$ & M4 sport \\
\hline 12. & 2018.03 .10 & DVSC & Újpest FC & $2017 / 2018$ & M4 sport \\
\hline 13. & 2018.03 .31 & Haladás & DVSC & $2017 / 2018$ & M4 sport \\
\hline 14. & 2018.04 .14 & DVSC & Ferencváros & $2017 / 2018$ & M4 sport \\
\hline 15. & 2018.04 .21 & Videoton & DVSC & $2017 / 2018$ & M4 sport \\
\hline 16. & 2018.05 .12 & DVSC & Diósgyőr & $2017 / 2018$ & M4 sport \\
\hline
\end{tabular}

Source: Own editing based on DVSC FUTBALL Ltd. (2018)

Tables 5 and 6 show that approximately half of the 33 games played by DVSC football club during a championship season are broadcasted by one of the national TV channels, of which the M4 sports channel broadcasts the most. TV broadcasting rights of clubs in the Hungarian football league are sold centrally by the Hungarian Football Federation. In order to be able to decide whether 16-17 broadcasted games per season is outstanding or low, it needs to be compared to the TV broadcast data of other teams. This case, comparison is based on the 2017/2018 champion Videoton and Diósgyôr, their relevant data are shown in Figure 4 and Figure 5.

Figure 4: Number of TV broadcasted games of the selected clubs during the 2016/2017 championship season

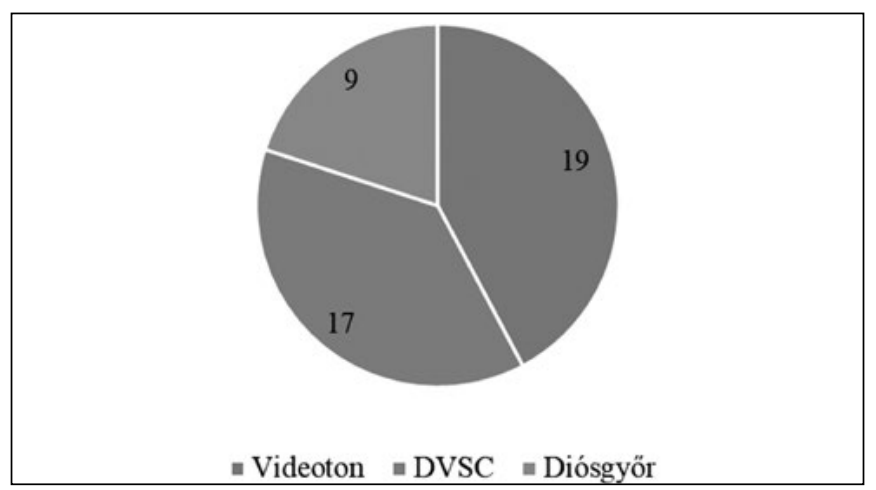

Source: Own editing based on DVSC, DVTK, Videoton (2018)
Figure 4 shows that 19 games of Videoton FC were broadcasted by one of the national TV channels during the 2016/2017 championship season.

Figure 5: Number of TV broadcasted games of the selected clubs during the 2017/2018 championship season

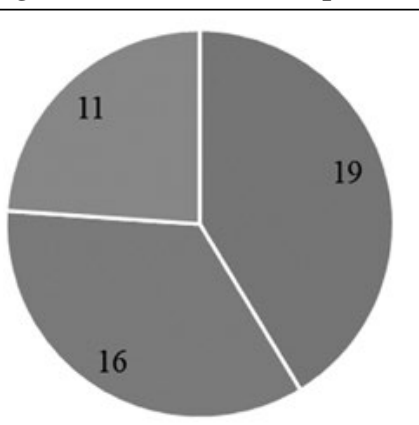

" Videoton $=$ DVSC = Diósgyőr

Source: Own editing based on DVSC, DVTK, Videoton (2018)

Figure 5 reveals that during the 2017/2018 championship season, Videoton FC had 19 TV broadcasted games again. Figures 4 and 5 show that in the case of Diósgyôr FC, the number of TV broadcasted games increased by two from the 2016/2017 championship season to the 2017/2018 championship season, while in the case of DVSC, one game less was broadcasted in the 2017/2018 season than in the previous one. It can be seen that DVSC had only three less broadcasted games than Videoton, which is a good result, since Videoton was competing for the championship title throughout the season and they have finally won it. Based on the above, it can be stated that the games of DVSC are frequently broadcasted on national TV channels, which might be attractive for sponsors. The club and the management do their best to increase this indicator, which is mostly influenced by the game performance and its quality. In the event that a football club is constantly competing for the championship title, there is a good chance that most of its games will be broadcasted by a TV channel, since in most cases, viewers are primarily interested in the games of another championship aspirants besides the games of their own favourite teams.

The final set up indicator in this perspective is the number of sponsorship contracts. The number of sponsorship contracts of the DVSC football club are shown in Table 7.

Table 7: Advertising/Sponsoring contracts of DVSC FUTBALL Ltd

Advertising/Sponsoring contracts of DVSC FUTBALL $\mathrm{cPlc}$

\begin{tabular}{|c|c|}
\hline $\begin{array}{c}\text { Number of Advertising/Sponsoring } \\
\text { contracts (pcs.) }\end{array}$ & Championship season \\
\hline 24 & $2016 / 2017$ \\
\hline 22 & $2017 / 2018$ \\
\hline 21 & $2018 / 2019$ \\
\hline
\end{tabular}

Source: Own editing based on DVSC FUTBALL Ltd. (2018) 
Table 7 clearly demonstrated that the number of advertising contracts shows a declining tendency, which does not necessarily mean that advertising-related revenue also decreases. The number of advertising contracts for the 2018/2019 season may still change as there is a possibility to sign new contracts during the season, either for a single occasion or for half of the season. The marketing department of the club constantly works to conclude as many new sponsorship contracts as possible and to extend existing contracts year after year. As mentioned earlier, the Hungarian market is unfortunately not willing and able to run football clubs on a business basis. The table also shows that there is a willingness on the part of the sponsors, as the club has already concluded 21 advertising contracts for the current season and there are still contracts that are under continuous negotiations.

The question is whether there is sufficient capital from the sponsors. The decrease in the number of sponsorship contracts is partly due to the less impressive performance in the championship season. However, it can be seen that the further efforts and the results of the last and current season might increase the number of potential sponsorship contracts. The 2018/2019 championship season lasts from July 1, 2018 to June 30, 2019, so there are still plenty of opportunities for signing new contracts, with potential new sponsors (DVSC FUTBALL Ltd.., 2018).

Sponsors have multiple options in terms the form of their appearance:

- shirt sponsors,

- main sponsors,

- $\quad$ stadium sponsors,

- $\quad$ advertisement placed along the field on advertising boards (DVSC FUTBALL Ltd., 2018).

Currently, the sports equipment sponsor of the DVSC football club is Adidas; the team plays in jerseys and sports equipment manufactured by the company. Most of the club sponsors choose to appear on the LED wall alongside the field and to be displayed on billboards or the various online platforms of the club. The aim of the club and management is to have as many main sponsors as possible (DVSC FUTBALL Ltd. 2018). Summarizing the index numbers of the customer perspective leads to the conclusion that there are areas where the club requires improvement but it performs well in most cases compared to its competitors.

\section{CONCLUSION}

Based on the findings it has been concluded the National League I football clubs in Hungary should also set up a controlling system to be able to develop and to operate on a market basis, just as large companies in the business sector. In the course of the research, the lack of a controlling system was clear; in order to associate results to index numbers set up in the scope of the study, the required data had to be requested from each of the divisions of the Ltd. This relatively long process is a disadvantage, and should not be acceptable, because information relevant to the decisions of the managers is needed as quickly as possible. In many cases, speed overwrites precision. Due to the lack of the system, these data do not match and do not form a complete system, so they are unable to serve as information for decision makers one by one. The reason the data does not work as a system is on the one hand that the club requires more professionals, so that it could operate more professionally and systematically.

The other reason is the lack of proper IT background that could be mitigated by a business management system or a business intelligence software.

By examining a possible BSC index system, it can be stated that the examined club has started to achieve its objectives. In the scope of the index system, figures of the club for the 2016/2017 season and the 2017/2018 season were compared. Examination the indexes set in the scope of the customer perspective of BSC shows that the analysed football club is still developing in certain areas, such as its stadium utilization rates and the number of sponsorship contracts. However, compared to competitors, the football club has the second highest attendance in the case of its home games.

\section{ACKNOWLEDGEMENTS}

The publication is supported by the EFOP-3.6.2-16-201700003 project. The project is co-financed by the European Union under the European Social Fund..

\section{REFERENCES}

Ács P. (2015): Sport és gazdaság, Pécsi Tudományegyetem Egészségtudományi Kar, Pécs, ISBN 978-963-642-372-8, pp. 601.

András K. (2003): A sport és az üzlet kapcsolata - elméleti alapok, 34. sz. Múhelytanulmány, HU ISSN 1786-3031, 2003. április, Budapesti Közgazdaságtudományi és Államigazgatási Egyetem. pp. 53.

Bácsné Bába É. (2015a): Sportszervezetek működési kereteinek változása KÖZÉP-EURÓPAI KÖZLEMÉNYEK (No. 28) VIII. évf.:(1.) pp. 151-161. (2015)

Bácsné Bába É. (2015b): Szervezeti változások sikeres sportvállalkozások esetében

TAYLOR: Gazdálkodás- és szervezéstudományi folyóirat A Virtuális Intézet Közép-Európa Kutatására Közleményei Vii. évf.:(3-4.) pp. 286-294. (2015)

Bácsné Bába É., Bács B.A., Bács Z. (2018a): Hazai professzionális labdarúgó klubok iparági elemzése International Journal of Engineering and Management Sciences (IJEMS) Vol. 3. (2018). No. 5DOI: 10.21791/IJEMS.2018.5.29.

Bácsné Bába É., Fenyves V., Szabados Gy., Dajnoki K. Müller A. Bács Z. (2018b):A Sportágazat Nemzetgazdasági Jelentőségének Vizsgálata Beszámoló Adatok Alapján 2014-2016-Os Időszakban Jelenkori Társadalmi És Gazdasági Folyamatok 13 : 3-4 pp. 93-103.

Bácsné Bába É., Balogh R., Bács Z., Fenyves V. Dajnoki K. (2018c): Sportszolgáltatások keresleti, kínálati oldalának elemzési lehetőségei STUDIA MUNDI - ECONOMICA 5 : 3 pp. 19-33. Paper: 10.18531/Studia.Mundi.2018.05.03.19-33 , 15 p.

Becsky, A. (2011): “The Application Of Balanced Scorecard In 
Team Sports," APSTRACT: Applied Studies in Agribusiness and Commerce, AGRIMBA, vol. 5(3-4), pages 1-4.

Biró M., Müller A.,Ráthonyi Ó.K., Ráthonyi G., Bácsné B. É., Dobay B. (2017): Az olimpiai játékok örökségei, különös tekintettel a gazdasági és társadalmi hatásokra.SELYE E-STUDIES $8: 1$ pp. 51-63.

Borbély A., Müller A. (2015):Sport és turizmus.Debrecen, Magyarország : Campus Kiadó (2015) , 110 p. ISBN: 9789639822368

Böcskei E., Bács Z, Fenyves V., Tarnóczi T. (2015): Kockázati tényezők lehetséges előrejelzése, a gazdálkodás felelősségének kérdése a számviteli beszámolóból nyerhetô adatok tükrében CONTROLLER INFO 2015/3 pp. 7-14. , 8 p.

Dénes F. (2015): Megéri a szponzoráció? Világgazdaság Online http://www.vg.hu/velemeny/megeri-a-sportszponzoracio-449795

Fenyves V. (2014): Vállalati teljesítményértékelés pénzügyi mutatók és a DEA felhasználásával

ACTA SCIENTIARUM SOCIALIUM 40 pp. 133-146. , 14 p. Fenyves V., Tarnóczi T., Bács Z., Böcskei E. (2016): Teljesítménymérés és értékelés - benchmarking és a DEA módszerrel CONTROLLER INFO 2016/4 : 4 pp. 2-9.

Fenyves V., Bács Z., Zéman Z., Böcskei E., Tarnóczi T. (2018): The Role Of The Notes To The Financial Statements In Corporate Decision-Making Corporate Ownership And Control $15: 4$ pp. 138-148. , $11 \mathrm{p}$.

Hágen I. Zs. (2017): A kontrolling szerepe, jelentôsége a hazai kis és középvállalkozások fejlesztésében CONTROLLER INFO 2017 : 1 pp. 95-103. , 9 p.

Hágen I. Zs., Kondorosiné (2011): Kontrolling kezdőknek és haladóknak, Controll 2003 Kft., Debrecen, 204 p., ISBN: 978963-88630-1-0.

Hamil S., Walters G., Watson L. (2010) The model of governance at FC Barcelona: balancing member democracy, commercial strategy, corporate social responsibility and sporting perfor-mance.Soccer \& Society Vol. 11, No. 4, pp. 475-504.

Horvath \& Partners (2004): Radikális váltás a VfB Stuttgart irányításában. Balanced Scorecard a Bundesligában http:// docplayer.hu/1662083-Radikalis-valtas-a-vfb-stuttgartiranyitasaban-balanced-scorecard-a-bundesligaban.html

Horváthová J., Mokrišová M., Suhányiová A., Suhányi L. (2015). Selection of key performance indicators of chosen industry and their application in formation of Creditworthy model. In: 9th International Scientific Conference on Business Economics and Management Location: Technical University of Zvolen. Vol. 34 (2015), pp. 360-367. ISSN 2212-5671. http://ac.els-cdn.com/ S2212567115016354/1-s2.0-S2212567115016354-main.pdf? tid=0e2e75d4-e9cb-11e5-a569-00000aab0f01\&acdnat $=14579 \overline{4}$ 9583 42e1e4723bac97280a4755807f33fb52

Kaplan R.S., Norton D. P (2004): Balanced Scorecard kiegyensúlyozott stratégiai mutatószámrendszer KJK-KERSZÖV Jogi és Üzleti Kiadó Kft. Budapset ISBN: 9632245423289.p.

Kocziszky Gy., Veresné Somosi M. (2016): Közszolgáltató szervezetek hatékonyságnövelésének lehetôségei ÉSZAKMAGYARORSZÁGI STRATÉGIAI FÜZETEK XIII. : 2. pp. 41-56. , $16 \mathrm{p}$.

Kozma G., Kazainé O. A. (2014a): Üzleti teljesítménymérés a sportban, avagy miként segítheti a sportszervezetk vezetőit a
Balamced Scorecard koncepció a stratégia szerinti múködésben 156. sz mủhelytanulmány ISSN 1786.3031 Budapesti Corvinus Egyetem http://unipub.lib.uni-corvinus.hu/1509/1/Kozma Kazai_156.pdf

Kozma G., Kazainé O. A. (2014b):Measuring business performance in sports. How the Balanced Scorecard approach can help sports organisations in operating along strategic objectives? Közgazdász Fórum XVII. évf 17-40. pp.

Kozma G., Kazainé O. A. (2014c) : Measuring Business Performance in Sports - How Revenue and Cost Calculations can Help Sports Organisations in Making Good Business Management Decisions Economics Questions, Issues and Problems, ISBN 978-80-89691-07-4 Proceedings of IRI Economics Conference, Komarno, Slovakia, 20-22. January 209-220.pp.

Kucsma D. (2017): Üzleti menedzsment közszférabeli adaptációjának kihívásai nternational Journal of Engineering and Management Sciences (IJEMS) Vol. 2. No. 4.DOI: 10.21791/ IJEMS.2017.4.23.

Musinszki Z. (2014): Cost to be a cost? Cost in the management accounting. In: Zéman Zoltán (szerk.): Controller Info Studies. Copy \&Consulting and Unio Publishing, 2014. 134-138. o. ISBN 9978-963-08-9751-8

Müller A., Bíró M., Váczi P., Herpainé L.J. (2016):Az olimpia hatásai a gazdaságra, társadalomra In: Juhász, György; Orsovics, Ivette; Nagy, Melinda (szerk.) Korszerű szemlélet a tudományban és az oktatásban = Súčasné aspekty vedy a vzdelávania : SJE Nemzetközi Tudományos Konferencia.Komárno, Szlovákia : Selye János Egyetem, 201) pp. 369-374. , 6 p.

Ráthonyi-Odor K., Borbély A. (2017): Sport finanszírozás - eredményesség?, GAZDASÁG- ÉS TÁRSADALOMTUDOMÁNYOK / SOCIAL SCIENCES, 2. évfolyam, 1-2. szám / Year 2, Issue 1-2, 2017, pp. 67-72.

Robert N., Vijay G. (2009): Menedzsment-Kontroll-Rendszerek, Panem Könyvkiadó Kft., Budapest, 848 p., ISBN. 978-963-545512-6.

Rodniski C. M., Diehl C. A., Zwirtes, A. (2013): Tableau De Bord: Proposal Of Application In Brazilian AgribusinessRevista Universo Contábil, ISSN 1809-3337 Blumenau, v. 9, n. 2, p. 63-82, abr./jun., 2013doi:10.4270/ruc.2013213

Suhányiová, A., Suhányi L., Mokrišová M., Horváthová J. (2015). Application of the Principle of Prudence in the Accounting of Slovak Businesses through the Creation of Adjusting Entries for Receivables. In: 9th International Scientific Conference on Business Economics and Management Location: Technical University of Zvolen. Vol. 34 (2015), pp. 311-318. ISSN 2212-5671. http://ac.els-cdn.com/S2212567115016354/1s2.0-S2212567115016354-main.pdf? tid=0e2e75d4-e9cb-11e5a569-00000aab0f01\&acdnat $=1457949583 \_42 \mathrm{e} 1 \mathrm{e} 4723 \mathrm{bac} 9728$ 0a4755807f33fb52

Szabados G. (2008) A labdarúgó klubok stratégiái. In: Kraúsz T., Mitrovits M.(szerk.): A játék hatalma: Futball-pénz-politika. Kelet-Európai Tanulmányok II. L'Harmattan Kiadó-ELTE BTK Kelet-Európa Története Tanszék Budapest, 2008 pp.58-76.

Széles Zs., Seben Z., Ferencziová D. (2014): CONTROLLING IN LOCAL MUNICIPALITIES (Kontroling v miestnych samosprávach) SELYE E-STUDIES 3: p. 1. 12 p. (2014)

Szóka K. (2018): THE APPEARANCE OF DIGITALISATION AMONG THE VIEWPOINTS OF BALANCED SCORECARD In: Jiri, Rotschedl; Klara, Cermakova (szerk.) Proceedings of the IISES Annual Conference Prága, Csehország : International Institute of Social and Economic Sciences (IISES), (2018) pp. 
284-301., 18 p.

Takacs, A. (2014): The Relationship between Appraised Company Values and Future Stock Prices in the International Banking Sector. International Research Journal of Finance and Economics, Issue 118, January 2014, 113-123.

Takacs, A. (2015): The explanatory power of appraised brand values on stock prices in the financial services sector. International Journal of Business Excellence, 8 (3): 298-311.

Váczi P., Ráthonyi O.K., Bíró M., Bácsné B.É., Bács Z., Ráthonyi G., Dobay B., Müller A. (2017):A különböző bajnoki rendszerben múködő hazai kosárlabda klubok gazdálkodási sajátosságai.SELYE E-STUDIES 2 pp. 102-117.

Veresné S. M. (2013): A szervezeti kompetencia- és képességépítés néhány sajátossága CONTROLLER INFO I. : 11. pp. 21-30. , $10 \mathrm{p}$. 